\title{
HAEMATOLOGICAL CHARACTERISTICS OF FRESHWATER-REARED AND WILD MULLET, MUGIL PLATANUS GÜNTHER (OSTEICHTHYES, MUGILIDAE)
}

\author{
Maria José T. Ranzani-Paiva ${ }^{1}$ \\ Carlos M. Ishikawa ${ }^{1}$
}

\begin{abstract}
Mullets, Mugil platanus Günther, 1880, were obtained from the estuarine area of Cananéia (São Paulo, Brazil) and from freshwater rearing tanks. For each fish the body weight, body length, gonad weight and gonad maturation stage were recorded and the allometric index $(\mathrm{K})$ was calculated. Blood was collected for hematocrit $(\mathrm{Ht})$, hemoglobin level $(\mathrm{Hb})$, total cell count $(\mathrm{Er})$, and the determination of hematological indices ( $\mathrm{MCV}, \mathrm{MCH}, \mathrm{MCHC}$ ), as well as the differential leukocyte count (lymphocytes, monocytes, neutrophils, basophils and "other cells"). The averages of the hematological analyses, hematological indeces, condition factor and leukocytes percentage of the specimens acclimated to fresh water were significantly higher than those of the specimens from the estuary.

KEY WORDS. Mugil platanus, haematology, mullet, freshwater rearing
\end{abstract}

The species of the Mugilidae represent a great potential in aquaculture, both for business and for repopulation, not only because they are adaptable to temperature and salinity variations and thus amenable to salt or fresh-water rearing, but also because they are well accepted by the consumer market. Besides, the mullet Mugil platanus Günther, 1880 has been cultivated in freshwater with great success (CARnevia et al. 1988; SCORvo Filho et al. 1992).

Mullets are eurithermic and eurihaline, and considered to be omnivorous, feeding on bottom detritus. Therefore, mullets are important in the efficient use of an aquatic environment (LIAO 1981), resulting in productivity increases. Mullets are commercialized in all areas where the species occurs, being an important protein source for man.

In spite of their present and potential value to aquiculture, the information available on Mugilidae adapted to fresh water is limited. Beyond a few studies on growth and weight gain, such as those by CARNEVIA et al. (1988) and SCORVO FILHO et al. (1992) mentioned above, little is known about the physiological condition of the species when adapted to fresh water. Therefore, this study compares the hematological characteristics of mullets reared in captivity with those of wild mullets.

1) Seção de Aqüicultura, Divisão de Pesca Interior, Instituto de Pesca (CPA-SAA). Avenida Francisco Matarazzo 455, 05031-900 São Paulo, São Paulo, Brasil. 


\section{MATERIAL AND METHODS}

In January, 1990, mullet fries, approximately $2.6 \mathrm{~cm}$ in length and weighing around $0.20 \mathrm{~g}$ were taken from coastal lakes, close to the estuarine area of Cananéia, Brazil, and acclimated to fresh-water rearing tanks on the Cacau-Açu Farm, near the city of Pariquera-Açu (São Paulo, Brazil), at a density of $1 \mathrm{fish} / 6 \mathrm{~m}^{2}$. After six months in captivity, 11 specimens were taken for haematological and parasitological analysis. The blood samples were collected by heart puncture using $3 \mathrm{ml}$ syringes with $8 \times 25$ heparinized needles. Heart puncture was chosen for being easy to perform and excellent for obtaining a large quantity of blood when applied to mullet. After obtaining the desired quantity of blood, the needle was withdrawn and the first drops of blood from the needle were used for the smears. At least four slides were prepared for each specimen, and after staining by the Leishman method, two of these were chosen for the differential counting. At least 200 white cells were counted in each smear.

The rest of the blood was used in the determination of: hematocrit, by the microhematocrit method, according to GOLDENFARB et al. (1971), using heparinized capillaries; hemoglobin level by the cyanometahemoglobin method, according to COLLIER (1944); erythrocyte or total cells count, done in a Neubauer chamber, using Hayem's diluent; hematological indeces according to WINTROBE (1934): mean corpuscular volume (MCV), mean corpuscular hemoglobin $(\mathrm{MCH})$ and mean corpuscular hemoglobin concentration (MCHC).

After the blood was collected the specimens were weighed (Wt -total weight in grams), and measured for total length (Lt -in centimeters). As soon as the biological data were recorded the fish were killed by pithing the brain.

A longitudinal incision from the anus to the cardiac cavity was made to expose the organs. At the macroscopic inspection of the gonads, the sex and their developmental stage were identified. The gonads were removed and weighed $(\mathrm{Wg}$ - in grams).

The allometric condition factor $(\mathrm{K})$ was calculated from the $\mathrm{Lt}, \mathrm{Wt}$ and $\mathrm{Wg}$ results according to ISAAC-NAHUM \& VAZZOLER (1983).

By the Student t-test, according CosTa Neto (1977) the average of the hematologic variants and the condition factor obtained for these samples were analyzed in relation to those for 71 exemplaries of the same length and gonad stage taken from the marginal lagoons of the estuarine region in Cananeia (Brazil) (RANZANI-PAIVA 1995) at the same time. Graphs were made using the amplitude of the variation, means and confidence intervals for each haematological analysis and for the condition factor of the two fish groups.

\section{RESULTS AND DISCUSSION}

The total length of the specimens obtained from freshwater tanks ranged from $14.4 \mathrm{~cm}$ to $17.2 \mathrm{~cm}$ and total weight from $29.35 \mathrm{~g}$ to $47.39 \mathrm{~g}$. The total length of the estuarine specimens ranged from $13.80 \mathrm{~cm}$ to $34.90 \mathrm{~cm}$ and total weight from $25.0 \mathrm{~g}$ to $290.0 \mathrm{~g}$. The gonads of all specimens were undifferentiated, that is, it was 
not possible to identify the sex by macroscopical examination. The means of the hematological analysis and of the condition factor calculated for the specimens acclimated in tanks were higher than those of the specimens obtained from the estuary (Tab. I). In figure 1 it can be noted that for $\mathrm{Ht}, \mathrm{Hb}, \mathrm{Er}$, and $\mathrm{K}$ there is not any overlap of the confidence intervals, suggesting a difference. This was proved by the Student $\mathbf{t}$-test, as significant differences were found at $0.25 \%$ probability for the means of $\mathrm{Ht}, \mathrm{Hb}, \mathrm{Er}, \mathrm{MCH}, \mathrm{MCHC}$ and $\mathrm{K}$. Thus the Ht increase was found to be statistically correlated with the increase in the number of erythrocytes, and not with the increase in cellular volume. The two groups showed no difference in MCV. Although there was little overlap of the confidence intervals for the MCHC, by the t-test the mean values are not significantly different. Table 1 also shows that the calculated $t$ for this index is very close to the critical $t$ of the $t$ table.

Table I. Amplitudes of variation $(A x)$, means $(\bar{x})$, standard deviation of the means $(S \bar{x})$, confidence intervals $(I \bar{x})$, and variation coefficient $(C V)$ of the hematological variants, $K$, and leukocyte percentage in the blood of the specimens of Mugil platanus, reared in freshwater tanks $(T)$ and obtained from the estuarine region in Cananéia, São Paulo, Brazil (E).

\begin{tabular}{|c|c|c|c|c|c|c|c|c|}
\hline Analyses & Environment & & $A x$ & $\bar{x}$ & $S \bar{x}$ & $\bar{x}$ & CV & t Student \\
\hline \multirow[t]{2}{*}{$\mathrm{Ht}$} & $\mathrm{T}$ & 21.50 & -45.00 & 36.36 & 1.71 & 3.82 & 16.36 & $4.48^{*}$ \\
\hline & $E$ & 15.00 & - 45.00 & 28.0 & 0.58 & 1.17 & 18.27 & \\
\hline \multirow[t]{2}{*}{$\mathrm{Hb}$} & $\mathrm{T}$ & 8.48 & - $\quad 11.89$ & 10.24 & 0.28 & 0.62 & 9.03 & $10.73^{*}$ \\
\hline & $E$ & 3.90 & - $\quad 10.71$ & 6.70 & 0.15 & 0.30 & 18.81 & \\
\hline \multirow[t]{2}{*}{$\mathrm{Er}$} & $\mathrm{T}$ & 221.50 & - 433.00 & 361.50 & 16.61 & 36.55 & 15.23 & $3.89^{*}$ \\
\hline & $E$ & 149.50 & -424.00 & 291.53 & 5.75 & 11.51 & 16.65 & \\
\hline \multirow[t]{2}{*}{ MCV } & $\mathrm{T}$ & 84.47 & - 120.66 & 101.02 & 3.12 & 6.86 & 10.23 & 1.13 \\
\hline & $E$ & 73.82 & - 157.80 & 96.73 & 1.78 & 3.56 & 15.42 & \\
\hline \multirow{2}{*}{ MHC } & $\mathrm{T}$ & 22.17 & $-\quad 51.15$ & 29.37 & 2.28 & 5.02 & 25.74 & $2.73^{*}$ \\
\hline & $E$ & 13.98 & - $\quad 33.26$ & 22.98 & 0.42 & 0.85 & 15.58 & \\
\hline \multirow[t]{2}{*}{$\mathrm{MCHC}$} & $\mathrm{T}$ & 21.20 & - $\quad 52.70$ & 29.22 & 2.32 & 5.12 & 26.43 & $2.21^{*}$ \\
\hline & $E$ & 14.44 & - $\quad 31.48$ & 23.97 & 0.36 & 0.72 & 12.72 & \\
\hline \multirow[t]{2}{*}{ K } & $\mathrm{T}$ & 22.58 & - $\quad 27.14$ & 25.29 & 0.39 & 0.86 & 5.14 & 34.26 * \\
\hline & $E$ & 8.14 & - $\quad 14.23$ & 11.58 & 0.13 & 0.26 & 9.59 & \\
\hline \multirow[t]{2}{*}{ Lf } & $\mathrm{T}$ & 16.30 & - 93.30 & 45.98 & 8.79 & 19.59 & 63.42 & 1.35 \\
\hline & E & 9.90 & - 99.00 & 58.69 & 3.45 & 6.89 & 47.42 & \\
\hline \multirow[t]{2}{*}{$\mathrm{Mn}$} & $\mathrm{T}$ & 0.00 & 5.90 & 2.38 & 0.69 & 1.54 & 96.22 & 0.40 \\
\hline & $E$ & 0.00 & - 42.00 & 1.72 & 0.67 & 1.34 & 316.28 & \\
\hline \multirow[t]{2}{*}{$\mathrm{Nt}$} & $T$ & 6.20 & - $\quad 77.70$ & 50.70 & 8.31 & 18.31 & 54.42 & 1.31 \\
\hline & $E$ & 0.50 & - $\quad 90.50$ & 38.87 & 3.43 & 6.86 & 71.19 & \\
\hline \multirow[t]{2}{*}{ Bs } & $\mathrm{T}$ & 0.00 & 2.40 & 0.49 & 0.23 & 0.52 & 159.18 & 0.22 \\
\hline & E & 0.00 & 5.00 & 0.55 & 0.13 & 0.26 & 189.09 & \\
\hline \multirow[t]{2}{*}{ Ot } & $T$ & 0.00 & 2.00 & 0.44 & 0.24 & 0.53 & 181.82 & 1.05 \\
\hline & E & 0.00 & 3.50 & 0.24 & 0.07 & 0.13 & 225.00 & \\
\hline
\end{tabular}

*. $p>0,5$. (Ht) Hematocrit (\%); (K) condition factor; (Hb) hemoglobin level ( $g / 100 \mathrm{ml})$; (Lf) lymphocyte (\%); (Er) erythrocyte numbers $\left(10^{4} / \mathrm{mm}^{3}\right)$; (Mn) monocyte (\%); (MVC) mean corpuscular volume $\left(\mu^{3}\right)$; (Nt) neutrophill $(\%) ;(\mathrm{MCH})$ mean corpuscular hemoglobin $(\mu \mu \mathrm{g}) ;(\mathrm{Bs})$ basophill (\%); (MCHC) mean corpuscular hemoglobin concentration (\%); (Ot) other cells (\%).

The values of the means of the hematological variants of the specimens from the tank are very close to those described by CONROY \& CONROY (1985) for Agonostomus monticola Bancroft, 1836, a mugilid species from mountain rivers, and are higher than those of the sea specimens (SOARES 1965; Pitombeira et al. 1969; GAVIRIA \& PÉREZ 1979). What is most evident is the high value for $\mathrm{K}$ in the specimens from the tank. 

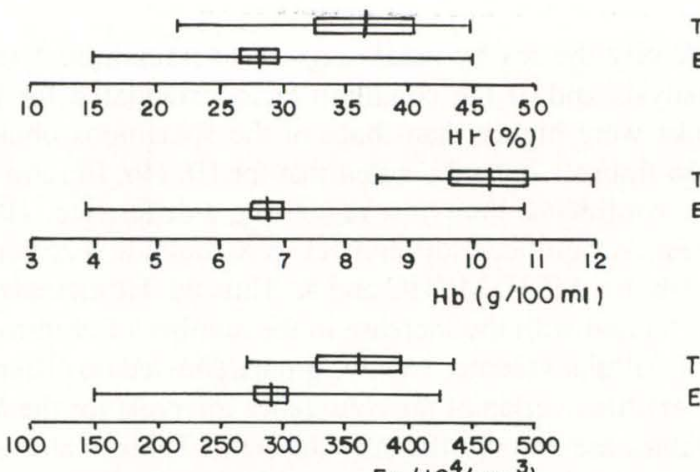

$\operatorname{Er}\left(10^{4} / \mathrm{mm}^{3}\right)$

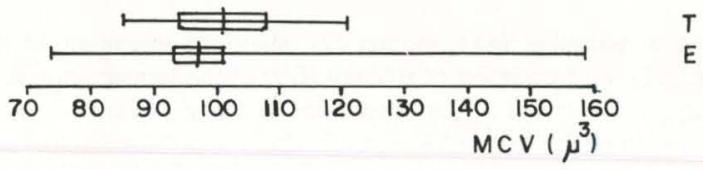

$T$
$E$
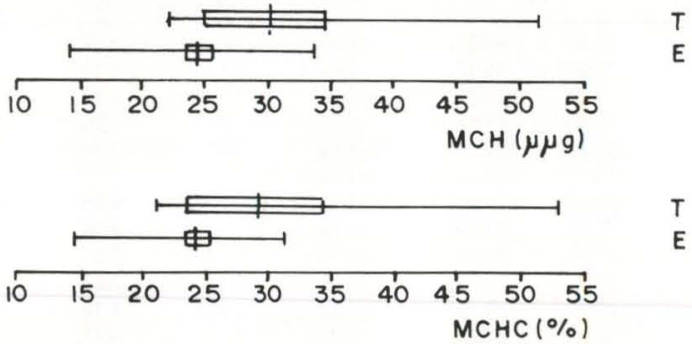

E

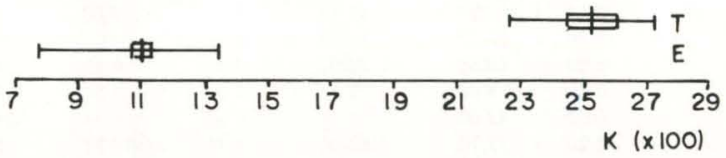

Fig. 1. Amplitudes of variation, means and confidence intervals of the blood analysis, the hematological indeces and $\mathrm{K}$ of the specimens of Mugil platanus, reared in freshwater tanks $(T)$ and obtained from the estuary (E).

CONROY et al. (1985), in studies done with Mugil curema Valenciennes, 1836 fry obtained in the same area of Cananéia considered in the present study, found that specimens of $2.6 \mathrm{~cm}$ presented great parasitological infestation. The authors describe the seasonality of the parasites and recommend that for best acclimatization in rearing tanks the capture of the fry should take place in August when, according to their data, cysts of heterophyid metacercaria were not found, preventing the introduction of Phagicola longa (Ransom, 1920) Price, 1932 in rearing tanks. It is suspected that this trematode can infest man by way of the ingestion of raw fish, causing gastrointestinal disturbances. Data for September in CONROY et al. (1985) indicate that $P$. longa is present even in mullet fry. In this 
study no parasites were found in the specimens from the tanks suggesting that ectoparasites that possibly came with the fry did not adapt themselves to the new environment; the freshwater ones, potentially pathogenic, had not yet been able to infest the new potential hosts. However, as a sample of the fish brought to the rearing tanks was not examined at the time of their capture from the lakes, it is not possible to state if they were already infested or not. PAPERNA \& LAHAV (1974) found a high mortality rate for Mugil cephalus Linnaeus, 1758 stocked in saltwater tanks, infested by copepod epizootics. However, in this same species stocked in freshwater tanks no specimen infested by this parasite was found, suggesting that the parasite, though common in saltwater fisheries, is not able to survive in water with low salinity. Our datas suggest that Mugil platanus rearing in freshwater tanks are able to be human food, without health risk.

Nevertheless, the physiological process of acclimatization to fresh water has not yet been studied for this species. CouRTOIS (1976), studying the marine species Morone saxatilis Walbaum, 1792, found significantly higher values for $\mathrm{Ht}$ and $\mathrm{Hb}$ in fish adapted to low salinity as compared to specimens from salt water. STANLEY \& COLBY (1971 apud COURTOIS 1976) found Ht increase in Alosa pseudoharenqus Wilson acclimated in fresh water, suggesting that the low Ht value for the specimens from salt water was due to the plasmatic volume expansion. Greater plasmatic volume dilutes the circulating blood, resulting in the lowering of $\mathrm{Ht}$.

Mavarez \& Perez (1984), studying 83 fish species of the family Sciaenidae, from both fresh and salt water, showed that the fresh-water fish presented higher values for $\mathrm{Ht}, \mathrm{Hb}$ and $\mathrm{Er}$ than fish from salt water.

Nevertheless, the conditions of confinement to which the fish were submitted could also generate the hematological differences, as was found by BURTON \& MurRAy (1979) and RANZANI-PAIVA \& Godinho (1986).

Concerning the leukocytes, it is evident in table I and figure 2 that there is no significant difference in the means of all cell types found for the specimens from the estuary as compared to those from the tanks.

The data present in this study, concerning mullets reared in freshwater, show that there is a physiological alteration, seemingly for the better, the condition factor is high in the specimens when kept in a confined environment and with a different salinity from that of their natural habitat. It is clear that more studies are necessary for this and other species in order to adapt them better to their new environment, to rationalize the rearing activity, and to enable better health control, with the aim of ensuring satifactory production.

\section{CONCLUSIONS}

The mullets reared in fresh water up to an age of six months present their blood characteristics significantly higher mean values than those of the specimens of same size and gonad stage captured in the estuary, suggesting that the adaptation to the new environment causes hematological changes, due to the erythrocytes number increase, and not due the cellular volume increase itself. 


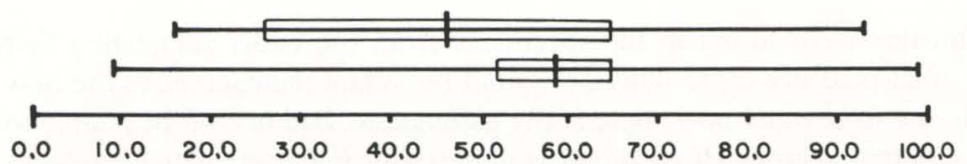

Lymphocytes $\quad(\%)$
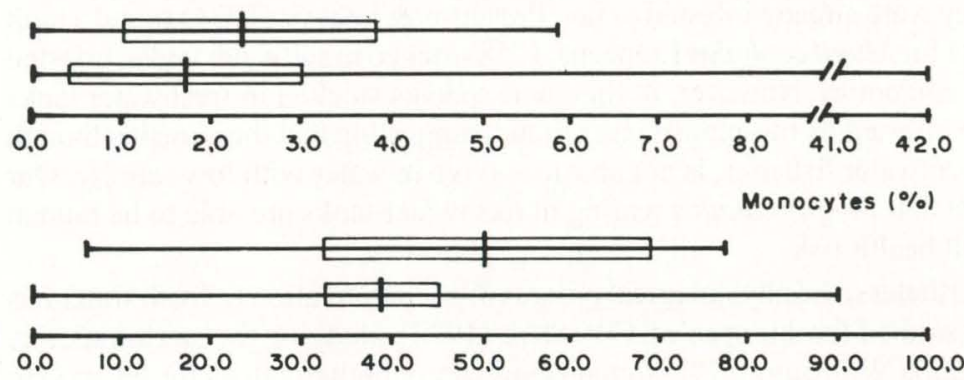

E
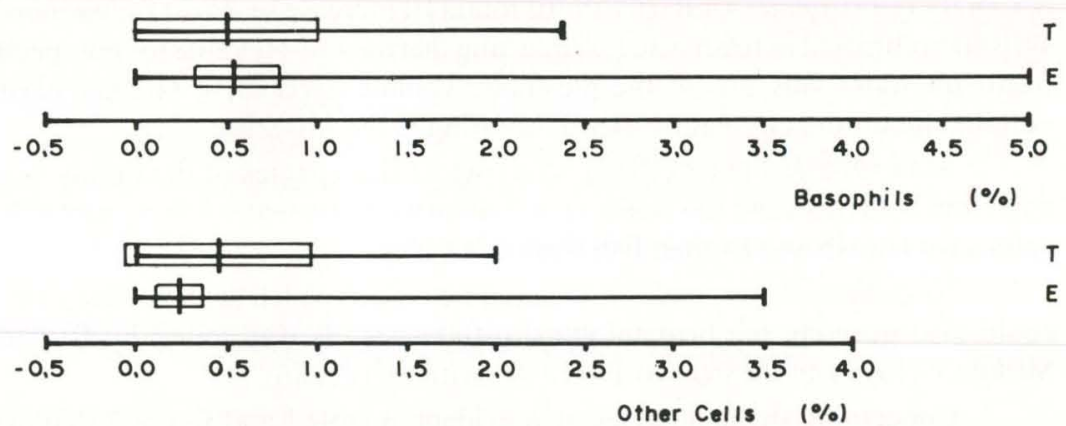

Fig. 2. Amplitudes of variation, means and confidence intervals of the leukocyte percentage in the blood of specimens of Mugil platanus, reared in freshwater tanks $(T)$ and obtained from the estuarine region of Cananeia, São Paulo, Brazil (E).

ACKNOWLEDGMENTS. The authors thank the technicians José Plaza and Hélio Sanches Mariscal, for collaborating with the collection of specimens, biologist Augusta Cocuzza das Eiras and graphic artist Regina Célia for drawing the graphs, and the Instituto Oceanográfico, Universidade de São Paulo, for the use of the laboratory in Cananéia.

\section{REFERENCES}

Burton, C.B. \& S.A Murray. 1979. Effects of density on goldfish blood - I. Hematology. Comp. Biochem. Physiol. 62 (3): 555-558.

Carnevia, D.; R. Mazzoni; O. Reosa; T. Eastman \& D. Lorenzo. 1988. Variaciones estacionales de diversas parasitosis en la lisa Mugil liza - Val. 1836 del Rio de la Plata. Resumos VI Simpósio Latinoamericano \& V Simpósio Brasileiro de Aquicultura, Florianópolis, p.299-304. 
Collier, H.B. 1944. The standardization of blood haemoglobin determinations. Can. med. Ass. J. 50: 550-552.

Conroy, D.A. \& G. Conroy. 1985. Observations on the haematology of the mountain mullet, Agonostomus monticola (Bancroft, 1836) in Venezuela. Riv. It. Piscic. Ittiop. 20 (3): 98-99.

Conroy, G.; D.A. Conroy \& P.S. Ceccarelli. 1985. Diseases and parasites detected in grey mullets (Mugilidae) from coastal waters of São Paulo State, Brasil. II. Juvenile silver mullet (Mugil curema Val., 1983). Riv. It. Piscic. Ittiop. 20 (2): 75-76.

Costa Neto, P.L. 1977. Estatística. São Paulo, Edgard Blüncher, 246p.

Courtois, L. 1976. Hematology of juvenile striped bass, Morone saxatilis (Walbaum), acclimated to different environmental conditions. Comp. Biochem. Physiol. 54 (2A): 221-223.

Gaviria, J.I. \& J.E. PÉrez. 1979. Parametros sanguineos en lisas, Mugil curema, en condiciones naturales y aclimatadas en agua dulce. Bol. Inst. Oceanogr. Univ. Oriente 18 (1): 89-97.

Goldenfarb, P.B.; F.P. Bowyer; E. Hall \& E. Brosious. 1971. Reproducibility in the hematology laboratory: the microhematocrit determination. Americ. J. Clin. Path. 56 (1): 35-39.

IsAaC-NAhum, V.J. \& A.E.A.M. Vazzoller. 1983. Biologia reprodutiva de Micropogonia furnieri (Desmarest, 1823) (Teleostei, Scianidae). 1. Fator de condição como indicador do período de desova. Bol. Inst. Oceanogr. 32 (1): 63-69.

LIAO, I.C. 1981. Cultivation methods, p.361-377. In: O.H. OREN (Ed.). Aquaculture of grey mullets. Cambridge University Press, 507p.

Mavares, R.N. \& J.E. PÉREZ. 1984. Blood adaptations to marine freshwater environments in fish of the Family Sciaenidae (Perciformes). J. Fish Biol. 25 (6): 657-663.

PAPERNA, I. \& M. LAHAV. 1974. Mortality among grey mullets in a seawater pond due to caligiid parasitic copepod epizootic. Bamidgeh 26 (1): 12-15.

Pitombeira, M.S.; F.V.B. Gomes \& J.M. Martins. 1969. Hematological data on the fishes of the genus Mugil Linnaeus. Arq. Cie. Mar 9 (2): 163-166.

Ranzani-Paiva, M.J.T. 1995. Caracteristicas hematológicas de tainha, Mugil platanus Günther, 1880 (Osteichthyes, Mugilidae) da região estuarino-lagunar de Cananéia - SP (Lat. 2500' - Long 475' 'W). Bol. Inst. Pesca 22 (1): 1-22.

RANZANI-PAIVA, M.J.T.\& H.M. GodINHO. 1986. Hematological characteristics of curimbatá, Prochilodus scrofa Steindachner, 1881 (Osteichthyes, Characiformes, Prochilodontidae) stocked in experimental conditions. Bol. Inst. Pesca 13 (2): 115-220.

Scorvo Filho, J.D.; E.R. Almeida-Dias; L.M.S. A Yrosa \& P.F. ColmerinhasNovato. 1992. Efeito da densidade sobre o desenvolvimento de alevinos de tainha listrada (Mugil platanus) em água doce. Bol. Inst. Pesca 19: 105-109.

SoARES, L.H. 1965. Alguns dados hematológicos de Mugil curema Cuvier \& Valenciennes. Bol. Inst. Biol. Mar. Univ. Rio Grande do Norte 2: 51-57. 
WINTROBE, M.M. 1934. Variations in the size and haemoglobin content of erythrocytes in the blood of various vertebrates. Folia Haematologica 51: $32-49$.

Recebido em 07.VI.1996; aceito em 22.X.1996. 